\title{
Sickness, disease and medical practitioners in 1640s Ireland
}

John Cunningham

In August 1642 a committee of MPs at Westminster urged the sending of more money to Ireland to maintain Protestant refugees there. Otherwise, they argued, 'there willbe an inevitable danger of their bringing over the infection of the pestilent fever with them, as hath bene allready done in some parts of Devon. ${ }^{1}$ The 1641 rebellion in Ireland clearly posed a risk not only to England's security, but also to its public health. In wartime Ireland, the dangers of violent death and disease loomed altogether much larger. This circumstance in turn presented opportunities and hazards to medical practitioners of various kinds. Any effort to study practitioners' experiences, and the Irish medical environment more generally, amidst the upheaval of the 1640s is inevitably hampered by the scarcity of relevant surviving sources. The latter problem is not unique to that decade; for most of Ireland beyond Dublin, we know little about medical practice in the seventeenth century. Fortunately, there is one extant source that enables a range of relevant insights into the situation in the 1640s. The Westminster committee's resolutions from August 1642 and an enormous quantity of additional information concerning the rebellion in Ireland are preserved in the same archive: the 1641 depositions.

The depositions are the best known and most controversial source for the history of Early Modern Ireland. They comprise around 8,000 witness statements and related material concerning the Irish rebellion of 1641 and its aftermath. ${ }^{2}$ For centuries after the event, the depositions were at the centre of heated debate around the question of what had actually happened in 1641 . Protestant writers pointed to their contents as evidence of a premeditated massacre by Catholics of very large numbers of English and Scottish settlers. ${ }^{3}$ Catholic writers in turn questioned the veracity of the depositions and refused to accept them 
as a reliable source for the history of the period. ${ }^{4}$ In recent decades the depositions have been put to new uses, for example in addressing questions of social and economic history and in literary studies of women's writing. ${ }^{5}$ While the violence and the killings continue to loom large in the historiography, since 2009 the availability of the depositions in edited and searchable format online has facilitated a wide range of fresh investigations. As Mark Sweetnam's study of Protestant clergymen has shown, the depositions can provide a means to explore the lives and experiences of particular groups of people within the wider context of rebellion and war. ${ }^{6}$ This chapter seeks to outline what the depositions can tell us about the history of health and medicine and, more especially, about medical practitioners in Ireland in the 1640s.

It is important to state at the outset that the relatively small quantity of relevant content in the 1641 depositions means that they are of limited use for the investigation of medical practitioners and practice in this period. While deponents from every county provided sworn statements rich in detail, the nature of the evidence is very far indeed from enabling general conclusions about numbers and types of medical practitioners active in Ireland at the time. Moreover, the medics who feature most prominently do so because of their involvement in war and politics, rather than their activity in the medical sphere. It is thus not possible to determine the extent to which the snippets of relevant evidence found in the 1641 depositions represent an accurate picture of Irish medicine more broadly at this time. While medical doctors, surgeons and apothecaries inevitably feature, as in other sources the wide range of sometimes unorthodox practitioners that existed outside of this triumvirate has left fewer traces.

Yet at the same time, the depositions allow us to identify practitioners not mentioned elsewhere. Given the limitations of the wider source base for the first half of the seventeenth century, it is worth paying attention to the depositions. The evidence they contain is sufficient to allow us brief but valuable glimpses into the lives of a number of practitioners located across the island. ${ }^{7}$ There are at least sixteen depositions directly provided by relevant individuals: four doctors of physic; one man who described himself as a 'Professor of Physicke'; seven surgeons; one surgeon's mate; one barber-surgeon; one barber; and one midwife. More than eighty further depositions sworn by a broad range of people - esquires, gentlemen, clergymen, widows and others - refer to named medical practitioners of various kinds. Many are only mentioned in passing; for others more detailed accounts of their 
activities are provided. This evidence relates to practitioners in twentyone of the thirty-two counties, while a physician and a apothecary from London also feature briefly. ${ }^{8}$ Before investigating this cohort in more detail, it ought to be worthwhile to explore what the 1641 depositions can tell us about experiences of sickness and disease in Ireland in that period.

\section{Sickness and disease in the depositions}

The 1641 rebellion encompassed various scenarios that led some deponents to comment on issues of health and sickness. These included: episodes of violence and physical assault; lengthy sieges; forced dislocation of people; theft of clothing; exposure to inclement weather; and shortages of food and water. Deponents' reflections on their experiences can provide insights into medical discourse in Early Modern Ireland. The word 'sickness' was sometimes used by deponents in a manner that conveyed a change of state due to the impact of the rebellion: a shift from being 'in health' into 'sickness'. On hearing a report of the death of his wife and children, Hilkiah Read of Co. Leitrim 'fell into sicknes whereof he soone after dyed.' Following the imprisonment of her husband in Sligo, Jane Stewart 'fell extreem sick: ${ }^{10}$ Elizabeth Bradley reported how a cold combined with grief to kill her husband: these 'did drive him into that sicknes whereof he (languishing) died. ${ }^{11}$ Illness that affected a group of people might be described in terms of a 'visitation'. Jonathan Hoyle, a Protestant minister in Queen's County, described how his family and servants (nineteen persons in total) 'were all of them (two or three excepted) visited with sore sickness. ${ }^{12}$ George Creighton, also a Protestant minister, deposed that 'sicknes came amongst us, and ... it pleased god this deponents wife died, All his family was visited (the deponent only excepted). ${ }^{13}$ This apparent tendency for clergymen to refer to 'visitation' highlights the providential framework within which they could understand sickness. ${ }^{14}$ Another clergyman, Richard Morse from Co. Fermanagh, was more blunt, ascribing the 'lamness and sickness' of his wife and children to 'the Cruell dealing of the Irish' in stripping them and forcing them to flee their home. ${ }^{15}$

For those who ultimately survived such hardship, the process of recovery could be long, or even remain incomplete. Morse reported that his family were 'scant well recovered' from their ordeal. ${ }^{16}$ Richard Gibson fled from Co. Carlow in mid-November 1641, 'though very 
sick.' Two months later he swore a deposition in Dublin, 'where he still languisheth of the same sicknes. ${ }^{17}$ In 1643 Calcott Chambre recounted how after 'falling sick [he] contynued in that sicknes for 16 weekes together', before recovering and making good his escape from the rebels in Co. Wicklow. ${ }^{18}$ Others were not so fortunate. William Oulton, a gardener, fled from Wexford by sea, only to be shipwrecked. After swimming ashore he was imprisoned in Arklow, Co. Wicklow, 'hauing in that restraynte Contracted sicknes \& becoming a criple. ${ }^{19}$ Oulton's testimony regarding his illness and disability reflected some of the perils that might accompany dislocation and imprisonment.

Deponents usually referred to 'sickness' in very general terms, sometimes alongside and interchangeably with 'disease'. John Massie from Queen's County reported his 'affliction by an extreame sicknes ... \& yet he is not cleared of the dangerous disease thereof. ${ }^{20}$ Richard Hobson, a vintner in Dublin, deposed that following a blow to the head his wife 'fell into a languishing sicknes \& disease which within a weeke killd her. ${ }^{21}$ From Co. Clare, John Ward revealed that the defenders of a number of besieged castles had become 'perplexed with sicknes, \& diseases. ${ }^{22}$ In the same county, those who fled to Ballyally Castle had to face food shortages as well as 'an infectious feauer then raigneing amongst them. ${ }^{23}$ Deponents were occasionally more specific about the nature of the ailments that they encountered. This reflected the heavy impact of particular diseases, as well as the existence locally of sufficient knowledge to identify the diseases in question. William Dethick, for example, was among the Protestants besieged in two castles at Tralee in Co. Kerry for seven months in 1642. The defenders lost relatively few men in skirmishes, but Dethick reported that about 140 men, women and children 'dyed out of both Castles through the sicknes called the Scurvey'. As refugees crowded into Dublin, observers noted the spread of contagious diseases there. In February 1642 Philip Bysse reported that 'Here are verie many deade Lately, especially of the poorer sorte, and the Chi[1]dren die verie thicke of measells and Poxe, my Cozen Jeffrey Phillips wife died of the Poxe in Childe bed, and now George kinge Grace Colmans husband hath the small Poxe. ${ }^{25}$ Two female deponents from the town of Armagh also reported cases of children with smallpox there in the early days of the rebellion. Isabell Gowrly recalled that two of her children 'hadd the smallpox visibly upvn them. ${ }^{26}$ The rebels' imprisonment of Protestants in cramped conditions and the flight of others to overcrowded places of refuge must have served to magnify the impact of diseases such as measles and smallpox. 
Among the keen observers of disease in Ireland at this time was the Dutch physician Arnold Boate. He moved to Ireland in 1636 and spent eight years there. His observations would help to inform Irelands Naturall History, a book written by his brother Dr Gerard Boate and published in London in 1652. ${ }^{27}$ The five 'diseases reigning in Ireland' mentioned by Gerard Boate included 'the Irish Agues' and 'the Loosness. ${ }^{28}$ The disease profile that he outlined for Ireland was to some extent reflected in the 1641 depositions. Boate explained that 'the Loosness' 'useth to turn to the Bloody flux', or diarrhoea, and was commonly known as the 'country disease. ${ }^{29}$ In Dublin in January 1642, Peter Bance reported the effects on his family of their being stripped and forced to flee from Co. Wicklow: 'his wife and children having gotten the Cuntry disease are now miserably sick ... whereby they are Like to perrish. ${ }^{30}$ Further north, Francis Sacheverell witnessed the deaths of Irish soldiers at Charlemont in Co. Armagh as a result of 'the bloudie fluxe. ${ }^{31}$ At the end of the decade, the 'country disease' would be one of the main challenges faced by Cromwell's newly arrived army. ${ }^{32}$

Boate described the 'Irish Agues' as 'a certain sort of of Malignant Feavers. ${ }^{33}$ The depositions detail several cases. Katherine Patman and her brother both deposed that their mother had been mortally wounded by a Scot, Thomas Boyd, in Co. Antrim in 1641. At the time, she had been caring for several family members 'sicke in an Ague' in the woods near their home. ${ }^{34}$ While Boate asserted that the 'Quartan Ague' was 'utterly unknown in Ireland', this is contradicted by the testimony of one deponent. ${ }^{35}$ In 1653 Edward Butler claimed that he had been 'surprizd with a quartan Ague' that forced him to 'keep his bed' in Co. Kilkenny for a month in the early days of the rebellion. ${ }^{36}$

Butler was one of several men who pleaded former ill-health when being interrogated by the Cromwellian authorities in the early $1650 \mathrm{~s}$ about their alleged involvement in the killing of Protestants more than a decade earlier. This naturally renders their testimony problematic, both in relation to their reported sicknesses as well as otherwise. It also reflects these men's hope that their claims of illness would be taken seriously in court. When flatly contradicted by witnesses, however, such pleas evidently carried little weight. Despite Butler's attempt to refute some of the charges against him by insisting that he had been bedbound, the Cromwellian High Court of Justice found him guilty of five murders at Ballyragget and he was duly executed. ${ }^{37}$

In Co. Antrim, the murder suspect Michael Doyne also claimed that he had been in poor health in 1641 . He insisted that he had been 'sicke 
of asore flux', for the treatment of which he sought a 'botle of Clared wine' from an acquaintance in nearby Belfast. ${ }^{38}$ Doyne, however, had not been confined to bed by his sickness and several witnesses provided evidence of his role in the upheaval. He too was found guilty of murder. ${ }^{39}$ In Co. Tyrone, ill-health also featured prominently in Patrick Modder O'Donnelly's account of his actions in 1641. O'Donnelly claimed that 'for three Moneths before the stirr he lay very sick in his own house'. Despite 'being very weake \& haveing taken Phisicke the day before', on 22 October he defied 'his Doctors rule' and went to the aid of local Protestants at Castle Caulfield. ${ }^{40}$ This version of events was directly contradicted by Captain John Perkins, who deposed that O'Donnelly had taken the lead in capturing Dungannon Castle from him on the same date. ${ }^{41}$ O'Donnelly's fate is unclear, but he certainly had reason to fear for his life in the face of Cromwellian murder investigations.

In the town of Galway in 1653-54, local officials seem to have made a determined effort to implicate the prominent Catholic lawyer and politician Patrick Darcy in an incident in March 1642 where a group of townsmen had surprised Captain Clarke's ship in the harbour and killed some of those on board. Under interrogation in Dublin in December 1653, Darcy insisted that at that time he had been 'sick in his owne howse' for around a month and that upon recovery he had left the town. ${ }^{42}$ Several witnesses provided evidence to contrary. Captain Hygate Lone recalled seeing Darcy 'in the streets the very day before the said surprisall but never heard that he was sicke. ${ }^{43}$ Both Jane Sheiley and John Morgan deposed that Darcy had been in health. ${ }^{44}$ Charles Conway 'Professor of Phisicke' expressed his belief that 'what was then done in Galway was by the direccion of Patricke Darcye, and the rest of the lawyers. ${ }^{45}$ Several other deponents were more circumspect, claiming ignorance of Darcy's whereabouts and his state of health in 1642 , and Darcy was ultimately released. ${ }^{46}$ While the reliability of the testimony provided by Darcy and his fellow prisoners is obviously open to question, claims about ague, flux and months spent sick in bed were all evidently viewed as plausible in the contemporary medical context.

The rebellion and the traumatic violent acts associated with it also inevitably had potential to impact on the mental wellbeing of those caught up in it. For this reason, it is worth paying some attention to cases where deponents referred to matters of mind as well as body. Although the relevant evidence is all too brief, it nonetheless offers a glimpse into contemporary perceptions. ${ }^{47} \mathrm{John}$ Sims from Co. Wexford deposed that his wife 'by frights taken by the cruelties of the Rebells is become very 
weake in body \& mynd, \& not like to Regaine her former strength. ${ }^{48}$ In Tuam, Co. Galway, a rape victim named Mary 'sayd that shee had layn sick vpon it for 3 or 4 dayes and was in such a condition that she thought shee should neuer bee well nor in her right mynd againe. ${ }^{39}$ In Co. Tyrone Mr Brodely's wife was reportedly 'fallen into an extreme frenzy' following robbery and stripping by the rebels. ${ }^{50} \mathrm{~A}$ number of deponents also described the distress experienced by perpetrators of violence and their associates, sometimes with an apparent undertone of divine retribution. ${ }^{51}$ Jane Stewart reported the murder of a woman by the friars in the town of Sligo, after which the prior of the convent 'fell franticke \& run soe about the streets \& contynued in that frenzie for 3 or 4 weekes. ${ }^{52}$ In Newry, Co. Down, Elizabeth Crooker claimed that Colonel Magennis was troubled on his death bed by a vision of Mr Tudge, a Protestant minister then recently executed there. In the same town, one of the rebels involved in prophaning the Protestant Church apparently 'fell into such $a$ trembling ... and extasy that other Rebells were gladd to carry him out of the Church as a frantick man. ${ }^{53}$ Such episodes can be usefully related to wider scholarship on psychological trauma resulting from Early Modern warfare, some of which has focused on gendered aspects of the relevant surviving narratives. ${ }^{54}$

In the depositions, perhaps the most frequently mentioned cases requiring medical treatment were the many cuts, stab wounds and gunshot wounds inflicted by the rebels on their victims and their opponents in arms. For example, at the surrender of Longford Castle Mathew Baker was wounded 'in twenty places with stabbs and cutts'; he died shortly afterwards. ${ }^{55}$ At Cashel in Co. Tipperary Ellice Meagher sustained ' 11 wounds'; she reported that her captors 'later plucked of [f] what plaisters were layd to theire wounds lest they should be cured. ${ }^{56}$ With medical provision in short supply, such cases very often resulted in a period of 'languishing' followed by death. Lack of surgical care was especially felt by soldiers. During the lengthy siege at Duncannon Fort in Co. Wexford, the anxious defenders lamented the garrison's 'want of a chirurgion': they complained that 'in case any of us Should receive any hurt, we are like to perish. ${ }^{57}$ One Protestant soldier who claimed to owe his life to a surgeon was Myles Jenkinson in Queen's County. Having taken two bullets in the back and a pike wound in his right arm, he prevailed on his captor to allow him to have his wounds dressed. ${ }^{58}$ Where such treatment was available it could prove expensive, especially for persons already deprived of their income and belongings. Samuel Felgate spend at least ten pounds in Dublin on treatment for two 
gunshot wounds, as well as the 'seven greivous wounds' suffered by his maid servant. ${ }^{59}$ In Co. Antrim a prisoner of the rebels, Thomas Ingram, agreed to pay five pounds towards the 'cure' of a sergeant whom he had shot in the thigh while attempting to evade capture. ${ }^{60}$ Given the extent of the violence and sickness apparent in wartime during the 1640s, it can be no surprise that there was strong demand for the services of medical practitioners of all kinds. What do the depositions reveal about the roles and experiences of such people?

\section{Doctors and apothecaries}

The relatively high social status enjoyed by medical doctors ensured that they achieved prominence across a variety of roles in 1640s Ireland. One well-known Protestant doctor who features in the depositions is the aforementioned Arnold Boate. He does so not because of his medical practice but rather because of his involvement in elite politics. In Dublin in July 1643 Boate was investigated for his alleged part in promoting two petitions: one for the removal of all Catholics from the city; and a second for subscribing 'some Covenant'. ${ }^{61}$ These activities were presumably related to the jostling for position ongoing within the Dublin government at that time. This situation arose because of a spilling over of royalist-parliamentarian tensions from England and also the unpalatable prospect of negotiations with the Catholic rebels. The consolidation of royalist control in Dublin in 1643 under James Butler, earl of Ormond, and the government's moves to secure Irish Catholic support for Charles I against the English parliament help to explain Boate's decision to leave Ireland shortly afterwards. ${ }^{62}$ Another doctor involved in politics at a high level in the 1640s was Gerald Fennell. He was a member of the Supreme Council of the Catholic Confederation that governed most of Ireland from its seat at Kilkenny and he was also a close associate of Ormond. ${ }^{63}$ Yet beyond his inclusion in a few listings by deponents of the names of the Catholic leadership, he is, like Boate, hardly mentioned at all in the depositions. This is so because he was not directly involved in the actions that informed much of the content of the depositions: the violence against and displacement of Protestants at a local level. The depositions have far more to say about two other Catholic doctors in that context.

In September 1652, Dr Donnogh O’Healy of Carnody in Co. Cork faced questioning about an incident that had occurred almost exactly a decade earlier. In mid-August 1642 a party of between twelve and 
sixteen Protestants was dispatched under armed Catholic escort from Macroom intending to travel to safe refuge in Cork, a distance of less than twenty-five miles. None of the prisoners reached their destination. O'Healy asserted that he had been on his way to visit a patient when he met the convoy on the road at Kilmurry. The next day, he heard that two of the prisoners had been hanged nearby, while the rest had been killed between Blarney and Cork. He was unable to recall the identities of most of the members of the escort because of 'his being soe much a stranger in his owne Country, for that he came but a yeare before out of ffrance.6 As many Irish Catholics received their medical education in France in the Early Modern period, this aspect of O'Healy's narrative can be seen as credible. ${ }^{65}$ Unfortunately for him, four members of the rebel escort deposed that O'Healy had taken custody of the two prisoners who were subsequently hanged at Kilmurry, a version of events reinforced by hearsay evidence from a number of other deponents. In at least fourteen depositions collected in 1652-53, O'Healy was implicated in the murders. According to this version of events, the doctor and two companions had met the convoy near Kilmurry. Upon identifying a nailer and a collier among the party, O'Healy had compelled them to go along with him, stating that he had need of their skills. Thereafter he was alleged to have hanged the two men and buried them in a sawpit. None of the deponents had actually witnessed these executions. The evidence against O'Healy was problematic, not least because the four key witnesses against him were understandably keen to absolve themselves of any blame for the deaths that had occurred. ${ }^{66}$ Nonetheless, their testimony was sufficient to ensure that O'Healy was convicted of murder in November 1652 and hanged at Cork. ${ }^{67}$

Another medical doctor, Daniel Higgins, was also executed by Cromwellian authorities in the early 1650s. In 1641-42, Higgins was involved in a number of actions in the Limerick region. ${ }^{68} \mathrm{He}$ is mentioned in at least nineteen depositions. Several deponents referred to him as 'of Limerick', while Dermod Grady stated that Higgins was from Scoul, a townland situated around eighteen miles south of the city ${ }^{69}$ Higgins was among the local Catholic leadership responsible for managing the successful siege of Limerick Castle in May-June 1642. He was also involved in an attack on Mallow, Co. Cork, in February 1642 and the subsequent siege of Lough Gur Castle about twelve miles south of Limerick. The latter siege lasted from March to September 1642. In two of the depositions collected in 1642-43 concerning events at Lough Gur, Higgins is identified as responsible for the death 
of Anthony Rindersly, a warder at the castle. Joseph Keanes accused him of 'first cutting of [f] one of ... [Rindersly's] ... armes \& stabbing of him in seuerall places ... and afterwards in a tormenting manner stripped him \& kepte him starke naked for Two dayes \& Two nights \& soe the man dyed. ${ }^{70}$ Higgins would never be brought to trial for this alleged murder. Following the surrender of Limerick to Henry Ireton in October 1651, he was one of the defenders executed in retribution for their role in delaying the surrender of the city ${ }^{71}$ Higgins provides a good example of how a medical doctor was able, and perhaps expected, to assume a leadership role at the local level.

At least one deposition links Higgins to a pursuit in which medical doctors and apothecaries played a key role during the early stages of the war in Ireland: the making of gunpowder. Apothecaries in particular were evidently expected to possess the expertise necessary to identify the ingredients of gunpowder and to oversee its manufacture. While the siege of Limerick Castle was underway in 1642, Higgins was entrusted with this task alongside others including James Hackett, an apothecary in the city. As part of an effort to procure sufficient quantities of saltpetre, graves were dug up in St Mary's Churchyard. ${ }^{72}$ Kilkenny witnessed similar scenes, where the rebels 'digged the tombes \& graues in the churches ... vnder colour of getting vp mowldes whereon to make gunpowder. ${ }^{73}$ The men who took responsibility for this vital work included Mr Munsell 'Doctor of Phissick' and the apothecary Edmund Sallenger. ${ }^{74}$ In the city of Waterford, the apothecary Richard Neylor was among those who 'digged vp some corps of protestants ... \& those they with the earth boyled in greate furnesses till they extracted saltpeeter, \& made of them gun powder worth three score pounds a weecke or therabouts. ${ }^{75}$ Beyond these instances of apothecaries making macabre use of their 'transferrable skills' for destructive ends, they appear to have left little other trace in the depositions. Yet it may be assumed that the war also stimulated demand for their more restorative products. ${ }^{76}$

The need for gunpowder also helped to shape the fate of one Dr Hodges in Ulster. This was the medic whose advice Patrick Modder O'Donnelly claimed to have ignored when he left his sickbed to go to the aid of Protestants at Castle Caulfield in $1641 .{ }^{77}$ Hodges's precise medical qualifications are unknown. One deponent, William Fitzgerald, explained that he was 'commonlie called in the Countrie Doctor Hodges for his practice of Phisick in the Northerne parts. ${ }^{78}$ Fitzgerald identified Hodges as one of Sir Phelim O'Neill's prisoners and 'cheife 
workmen' in a largely unsuccessful attempt to make gunpowder for the Ulster rebels at Charlemont and Armagh. ${ }^{79}$ George Wirrall from Co. Fermanagh, who had previously been employed as 'a clerke and paymaster' to a London saltpetre master, was among those selected to 'learne the faculty' of gunpowder manufacture from Hodges. Wirrall discovered that Hodges had only managed to produce seven ounces of 'very unprofitable stuffe' and he suspected that the doctor was deliberately sabotaging the process. The rebels' patience was soon exhausted. ${ }^{80}$ While Hodges's wife and two sons escaped, he was reportedly halfhanged and then imprisoned for a further three months, before being killed in a massacre near Charlemont. ${ }^{81}$

The high profile enjoyed by doctors ensured that a number of others were mentioned more briefly in the depositions, either as rebels, as victims, or otherwise. Dr Derby O'Connor in Co. Tipperary and Dr John Field in Co. Kerry were both reported to be in rebellion. ${ }^{82}$ Stephen Love deposed that Field had taken a local leadership role on the rebels' county committee in Kerry and he denounced him as 'a most pestilent and pernitious enemy to the English-nation. ${ }^{83}$ From the Scottish settlement at St Johnstown in Co. Longford, Elizabeth Stewart reported losses worth $£ 162$ 8s. suffered by her and her late husband Alexander Stewart 'Doctor of Phissick'. These losses included income from houses and land, books worth fourteen pounds and a salary of twenty pounds payable for running the school at St Johnstown. The deposition does not make clear whether it was Elizabeth or Alexander, or both of them together, who received this salary, nor is there any indication of the scale of Alexander's income from his medical practice. ${ }^{84}$ Two prominent English doctors associated with the parliamentarian army, William Petty and Abraham Yarner, were among the commissioners appointed by the government in 1652 to collect evidence relating to murders in 1641. Their signatures appear together on a number of depositions relating to Co. Meath. ${ }^{85}$ The only physician mentioned in the depositions because of actual practice during the rebellion seems to be William Connery of Carrigrenny in Co. Cork. Under examination in 1652, he recounted having dressed the wounds of two wounded soldiers of Lord Inchiquin's who came to his house. He was later forced to hand them over to the rebels. ${ }^{86}$ As other depositions confirm, Connery's actions in treating soldiers' wounds were more typically the preserve of surgeons in this period. Yet given the wartime context, it is hardly surprising to find a physician doing the work of a surgeon. 


\section{Barbers, surgeons and barber-surgeons}

In Early Modern Ireland, as elsewhere, the occupational labels of barber, surgeon and barber-surgeon were not always used consistently in various sources, so that a man described as a 'barber' in one place can sometimes appear elsewhere as a 'surgeon'. For this reason, it cannot be assumed that the labels used reflected any actual division of labour between the tasks of cutting hair, trimming beards, lancing boils, letting blood, performing operations, treating wounds, and so on. The word 'surgeon', or its now archaic form 'chirurgeon', also provides a good example of the remarkable diversity of spelling evident within the 1641 depositions. For instance, the official responsible for taking down the examination of Mullmory O'Loney from Co. Fermanagh rendered his occupation as 'kirurgeon'. O'Loney claimed to have arrived in Dublin on 22 October 1641 'to gett a service vnder somme Phisician or surgeon' in the city ${ }^{87}$ If this was the truth, then it was his considerable misfortune to have arrived on the same day as a group of rebels intent on surprising Dublin Castle. They were led by Lord Maguire, who like O'Loney was also from Co. Fermanagh. ${ }^{88}$ The authorities concluded that O'Loney was most likely the rebels' surgeon; his fate is unknown. ${ }^{89}$ $\mathrm{He}$ is one of the ten surgeons associated with the rebels who can be identified in the depositions.

Some of the most detailed relevant information from the rebel side was gathered from men taken prisoner by government forces at Rathcoffey and other castles in Co. Kildare in mid-1642. Charles Connor of Kildrought, Co. Kildare, was a surgeon who had been part of the company of Captain Gerald Fitzgerald. He recounted to the authorities in Dublin his recent movements around Kildare and in west Co. Dublin, naming and implicating a large number of local Old English gentry families in the rebellion. He had done the 'Office of his calling' in the rebel camp at Leixlip, and repaired to Lady White's house at St Katherine's 'there to do cures'. He had also been summoned to let the blood of a priest's servant at Luttrellstown and of Mr Eustace's daughter at Confey. According to Connor, Lady White, Mr Luttrell and Eustace were all 'well knowing' of his status as a rebel, the implication being that their employment of him showed their sympathy with the rebel cause. Luttrell had even asked Connor to 'trim' him. ${ }^{90}$ The war evidently created new opportunities for Connor in treating rebel soldiers, alongside his addressing the local gentry's needs for bleeding and trimming. ${ }^{91}$ 
Two other depositions taken from prisoners captured at Clongowes Wood Castle in Co. Kildare provide some further insight into the medical provision available to the rebels in that county. Thomas Fitzgerald explained that following a fall from his horse he had travelled to Clongowes Wood to be treated by 'a woman called mary barnewall which had skill in Chirurgry.92 His comrade David Eustace deposed that 'mary Barnewall tooke ... [Fitzgerald] ... in hand to cure him and did cure him reasonable well. ${ }^{93}$ These references to Barnewall represent rare explicit evidence of a woman practising surgery in Ireland at this time. While the records of the guild of barber-surgeons in Dublin contain mentions of female practitioners, usually widows continuing their deceased husbands' trades, a paucity of relevant sources means that such individuals are even harder to uncover in the rural context in which Barnewall was operating. ${ }^{94}$ The circumstances of her training and of her practice of surgery in the longer term can only be guessed at. As with Connor, the war presumably provided new opportunities for Barnewall to practise.

Among the Protestant victims of the rebellion, the depositions record the killing of a barber in Rosscarbery, Co. Cork, and another in Tralee, Co. Kerry, as well as the murder of a surgeon in Armagh..$^{95}$ The latter, William Wollard, was reportedly killed by a man whom he had recently successfully treated for a wound in his arm. ${ }^{96}$ The depositions include testimony from four Protestant surgeons relating to their wartime experiences. In Co. Tipperary, Richard Sheapheard, 'chirurgian', provided no details of his practice. His reported losses consisted largely of animals and crops, as well as the lease on his house and farm. ${ }^{97}$ Robert Rawlins was the surgeon on Captain Clarke's ship when it was attacked at Galway in 1642. Eleven years later, he provided a detailed eyewitness account of the attack, including a tussle during which he had been stabbed in the shoulder and then rescued by a stranger carrying a carbine. ${ }^{98}$ Two further Protestant surgeons provided some details of their practice during the rebellion. The first was John Mandlefeild, of Dunlavin, Co. Wicklow, seemingly the only person referred to in the depositions as a 'Barber Chirurgion. Mandlefeild lost his 'barbers tooles and instruments' to the rebels. Despite this, he was able to cure his wife. She had been stabbed in the breast, causing a wound that Mandlefeild had 'with much difficultie healed after his wiffs great paine endured.9 Another Protestant deponent, William Sterling of Ballymoney, Co. Antrim, described himself as a gentleman, albeit one 'who professed Chirurgery'. Sterling claimed to have successfully treated John Hunter 
for 'fifteene or sixteene stabbs with a pike in his backe. ${ }^{100}$ Sterling may have exaggerated his success, however, as a separate deponent reported that Hunter had died of his wounds. ${ }^{101}$ The example of Sterling moves us towards the final group to be considered: those individuals whose primary descriptors of occupation or status in the depositions do not indicate the practice of medicine. For these, a variety of other clues have to be sought out.

\section{Other practitioners}

In the 1641 depositions, the status of the vast majority of the female deponents is stated in terms indicating their relationships to men, with most being either described as either 'wife' or 'widow'. This approach is of course characteristic of Early Modern sources more broadly and it reflects broader contemporary assumptions about women's social status and the nature and value of their work. It also poses a variety of problems for historians interested in the latter subjects. Fortunately, the depositions provided by some women in 1640s Ireland provide indications of particular skills possessed by them, or of the type of specialised work that they could undertake. This can be seen, for example, in cases where impoverished Protestants who escaped to Dublin sought help from officials to secure employment that would enable themselves and their families to subsist.

One such individual was Elizabeth Adwick, 'wife to Thomas Adwick gent'. Adwick was a thirty-five-year-old woman from Castlewaterhouse in Co. Fermanagh. Having been robbed of her possessions at the outbreak of the rebellion, she fled her home and reached Dublin by early January 1642. In her deposition she stated that her husband Thomas was absent, having gone to the West Indies three years earlier. Without her husband and deprived of her land, crops and animals, Adwick faced an uncertain future. But her chances of survival were certainly enhanced by the very valuable skills that she claimed to possess. Her deposition reveals that 'She hath skill in doeing the office of a midwife, by the which if she had any clothinge to goe abroad, she hopes to live. ${ }^{102}$ The latter detail was recorded as a marginal note, while Adwick's primary social status as 'wife' appeared at the opening of her deposition. This document points to some of the difficulties associated with identifying women who engaged in medical practice. While the depositions cannot be expected to tell us much about women's diverse involvement in household medicine and the care of family members, 
the tendency in such official sources to privilege the labels of 'wife' and 'widow' makes it much more difficult to identify those who were active beyond their immediate households. ${ }^{103}$ Adwick is the only one of the hundreds of female deponents who can be positively linked to a medical occupation.

Just one other named midwife is mentioned in passing in a deposition: Alls Browne was reportedly killed by the rebels during a siege at Cullen Castle in Co. Tipperary in August 1642. ${ }^{104} \mathrm{~A}$ few more midwives are referred to, accompanying pregnant women in one case, and attending a birth in another. ${ }^{105}$ Unfortunately, these latter midwives are not identified by name. This is of course a reminder of another of the many difficulties that surrounds efforts to identify female medical practitioners in Early Modern sources more generally. It is one that sometimes arises in connection with male practitioners too, for example in the case already mentioned above of Myles Jenkinson's treatment by an anonymous surgeon. Another instance in the depositions is the unnamed ship's surgeon killed in a skirmish near Kenmare in June $1642 .{ }^{106}$ The case of William Wilkinson of Benburb in Co. Tyrone illustrates another type of challenge that can be encountered in relation to identifying medical practitioners. Two or three years before the rebellion he had reportedly 'releeved \& recovered' his sick and bedridden Catholic neighbour Shane Ó Hagh. On the outbreak of the rebellion, however, Ó Hagh had seized Wilkinson's house and murdered him. The evidence here is not sufficient to determine whether Wilkinson was a recognised medical practitioner of some sort, or simply a kind and useful neighbour. ${ }^{107}$

The depositions also provide some details of other instances where the precise nature of the medical practice concerned is unclear. In King's County, a gentleman named Henry Aylyffe reported the loss of 'druggs for Phissick. ${ }^{108}$ These may simply have been intended for the use of his household; there is no suggestion in Aylyffe's lengthy testimony that he or his wife had any particular medical knowledge or skills. Another gentleman, Thomas Andrew of Ballinaglera in Co. Clare, reported more substantial losses of items with obvious medical purpose. In December 1641 he was robbed 'Of Bookes to the value of foure pounds nine shill[ings] Of siluer Instruments of Chirurgery to the value of seaven pounds $5 \mathrm{~s}$. Of Phisicall druggs potts \& glasses belonging thervnto to the value of thirteene pounds. ${ }^{109}$ If these were just the house contents of a gentleman seeking to provide against the inevitability of ill-health among his family, then he was certainly well stocked. It seems possible 
that Andrews was equipped to practise medicine more widely. Yet in terms of the value of his losses in the rebellion, the medical paraphernalia were far outweighed by farm animals, crops and impliments of husbandrie.' ${ }^{110}$ The 'chirurgian' Richard Sheapheard reported mainly losses of an agricultural nature while the 'gentleman' Thomas Andrew possessed a range of medical equipment. ${ }^{111}$ This serves as a caution against seeking to impose too rigid a scheme of occupational differentiation, of medical practitioners and non-practitioners, especially in remote areas of the Irish countryside in the seventeenth century. It also points to the likelihood of widespread self-medication, a practice that James Kelly has analysed in Ireland from the mid-seventeenth century onwards. ${ }^{112}$

One group of depositions where we might expect to see evidence of cross-over between medicine and other pursuits is in those relating to clergymen. ${ }^{113}$ The deposition of George Creighton, vicar of Lurgan in Co. Cavan, reveals his familiarity with medicine of the veterinary kind. While he was a prisoner of the rebels at Virginia, he became aware of an outbreak of 'a greivous plague amongst the Cowes of Meath and many died by pissing bloud. ${ }^{114}$ Creighton advised the rebels to consult the copy of 'Gowges husbandry' housed over thirty miles away in the earl of Fingall's library. ${ }^{115}$ When the book was brought to him, he was able to find the appropriate remedy, which 'prooved soe effectuall that the disease stayd. ${ }^{116}$ Elsewhere in the depositions, two instances of clergymen using their medical skills for the benefit of besieged Protestants can be identified. Few deponents could boast the degree of diversity in wartime employment attained by Edward Williamson. When the rebellion broke out, he was around sixty years old and possessed of a church living worth eighty pounds per annum at Monasterevin in Co. Kildare. He promptly fled to the castle at Monasterevin, where he served as 'a preacher Chirurgion \& souldjer in the garrison for a yere and nyne moneths vntill it was surrendred.' ${ }^{117}$ At Knockvicar in Co. Roscommon, Dr Ambrose Frere held out against the rebels for fourteen months. ${ }^{118}$ The deposition of Ann Frere, his widow, reported his successful 'cure \& help' of Stephen Bonner, who had been shot in the thigh. Unfortunately for Dr Frere, he later suffered a similar wound in the topp of his thigh soe dangerously with a gnawd or chattered bullett, that the wound festered \& grew to a gangrene \& contynued soe that within six dayes after hee died. ${ }^{119}$ For Frere, as for many others mentioned in the depositions, no indication is given of where he acquired his medical knowledge or how widely he practised. 


\section{Conclusion}

In relation to sickness and disease, the 1641 depositions contain brief snippets of evidence concerning a broad group of people. This brevity precludes much by way of in-depth analysis in many instances. At the same time, the breathless immediacy of the evidence, much of it provided by victims and eyewitnesses who otherwise left no trace in the archive, helps to make the 1641 depositions an intriguing source. Careful sifting of these documents can enrich our understanding of experiences, understandings and representations of violence, pain, death, disability, sickness and disease in Early Modern Ireland. ${ }^{120}$ The discussion above has offered just a flavour of the relevant evidence, which even post-digitisation continues to pose a range of practical and interpretative difficulties to scholars. The depositions' value as a source for medical practitioners is likewise due to their breadth. More than 100 depositions contain some mention of individuals who practised medicine, and again many of these persons are not found in any other source. Yet the depositions are very far from enabling anything close to a systematic analysis of numbers and locations of medics in the 1640s. They instead provide a haphazard snapshot of some medical practitioners in some parts of Ireland in that decade. There are certainly gaps in the picture that they offer, and much blurring at the edges. It is perhaps at these edges that the 1641 depositions are most useful. They emphatically remind us that Ireland's medical world was not solely comprised of neat categories of clearly labelled practitioners, always distinguishable from the wider population. After all, a gentleman might possess the best stock of medical provisions for miles around, and a surgeon might devote most of his attention to agriculture. In time of war, the edges could become even more blurred. A preacher might take on surgery or soldiery as circumstances demanded. A doctor might heal one man and hang another. And the apothecary might boil the corpse.

\section{Notes}

1 TCD, MS 840, 'Reasons for early payments of sums to the poor of Ireland', 15 Aug. 1642, fos 55r-6v.

2 The depositions have been edited and digitised. They are freely accessible at 1641.tcd.ie.

3 John Temple, The Irish Rebellion (London, 1646).

4 John Curry, Historical Memoirs of the Irish Rebellion in the Year 1641 (London, 1758); T. Barnard, '1641: a bibliographical essay', in B. Mac 
Cuarta (ed.), Ulster, 1641: Aspects of the Rising (Belfast, 1993), pp. 17386; J. Gibney, The Shadow of a Year: The 1641 Rebellion in Irish History and Memory (Madison, WI, 2013).

5 N. Canny, 'The 1641 depositions as a source for the writing of social history', in P. Flanagan and C. Buttimer (eds), Cork: History and Society (Dublin, 1993), pp. 249-308; M.-L. Coolahan, Women, Writing, and Language in Early Modern Ireland (Oxford, 2010), chapter 4.

6 M. Sweetnam, "Sheep in the midst of wolves"? The protestant ministry in the 1641 depositions', Journal of Irish and Scottish Studies, 6 (2013), pp. 71-92.

7 The medical practitioners discussed below have been identified in the 1641 depositions by means of searches of the relevant website at 1641 . tcd.ie. The relevant data will be made available in due course on the online database of the Early Modern Practitioners project at Exeter. See practitioners.exeter.ac.uk.

8 In his evidence, Edward Lake, alderman of Dublin, referred to a recent stay in London where he met Thomas Hicks, an apothecary of Fleet Street, and a Doctor Moore. TCD, MS 809, Examination of Edward Lake, 12 Nov. 1641, fos $164 \mathrm{r}-5 \mathrm{v}$.

9 TCD, MS 831, Deposition of Ann Read, 12 July 1642, fos 39r-40v.

10 Ibid., Deposition of Jane Stewart, 16 May 1653, fos 120r-1v.

11 TCD, MS 813, Deposition of Elizabeth Bradley, 17 Dec. 1644, fos 303r-4v.

12 TCD, MS 815, Deposition of Jonathan Hoyle, 18 Jan. 1644, fos 330r-3v.

13 TCD, MS 833, Deposition of George Creighton, 15 Apr. 1643, fos 227r-42v.

14 On this point, see H. Cleugh, "At the hour of our death": praying for the dying in Post-Reformation England', in E. Tingle and J. Willis (eds), Dying, Death, Burial and Commemoration in Reformation Europe (Farnham, 2015), pp. 50-3.

15 TCD, MS 835, Deposition of Richard Morse, 31 Dec. 1641, fos 143r-4v.

16 Ibid.

17 TCD, MS 812, Deposition of Richard Gibson, 15 Jan. 1642, fos 14r-15v.

18 TCD, MS 811, Deposition of Calcott Chambre, 24 May 1643, fos 174r-5r.

19 TCD, MS 819, Deposition of William Oulton, 14 Mar. 1654, fo. 253r-v.

20 TCD, MS 815, Deposition of John Massie, 2 May 1643, fo. 342r-v.

21 TCD, MS 810, Deposition of Richard Hobson, 31 Aug. 1644, fo. 296r-v.

22 TCD, MS 829, Deposition of John Ward, 25 Apr. 1643, fos 80r-5v.

23 Ibid., Deposition of John Hawkins, 29 Oct. 1642, fos 66r-7v.

24 TCD, MS 828, Deposition of William Dethick, 27 May 1643, fos 236r-7v. Gerard Boate claimed that scurvy did not exist in Ireland at this time. See his Irelands Naturall History (London, 1652), p. 178.

25 TCD, MS 840, Letter from Philip Bysse to his brother, Dublin, 16 Feb. 1642 , fos $7 \mathrm{r}-10 \mathrm{v}$. 
26 TCD, MS 836, Deposition of John and Isabell Gowrly, 8 Nov. 1642, fo. $57 \mathrm{r}-\mathrm{v}$ and Examination of Magdalen Duckworth, 10 Feb. 1653, fos $121 \mathrm{r}-2 \mathrm{v}$.

27 Boate, Irelands Naturall History.

28 Ibid., pp 182-3.

29 Ibid.

30 TCD, MS 811, Deposition of Peter Bance, 19 Jan. 1642, fo. 26r-v. See also John McCan's report of the death of Henry Stanaway at Armagh in TCD, MS 836, fo. 219r-v.

31 Ibid., Deposition of Francis Sacheverell, 21 July 1643, fos 107r-11v.

32 See for example, Cromwell's letter to Speaker Lenthall, 25 Oct. 1649 in S. Lomas (ed.), Letters and Speeches of Oliver Cromwell with Elucidations by Thomas Carlyle (3 vols, London, 1904), i, p. 496.

33 Boate, Irelands Naturall History, p. 181.

34 TCD, MS 838, Examination of Roger Gill, 28 Apr. 1653, fo. 282r-v and Examination of Kathrin Patman, 28 Apr. 1653, fos 282v-3v.

35 Quartan ague is a form of malaria, which causes a fever that recurs every fourth day.

36 TCD, MS 812, Examination of Edward Butler, 16 Feb. 1653, fos 327r-8v.

37 J. Wells, 'Proceedings at the high court of justice at Dublin and Cork 1652-1654 [part 2]', Archivium Hibernicum, 67 (2014), pp. 234, 249-50.

38 TCD, MS 838, Declaration of Michael Doyne, undated, fos 108r-12v, Examination of Michael Doyne, undated, fos 113r-14v and Examination of Michael Doyne, 24 Aug. 1653, fos 115r-16v.

39 J. Wells, 'Proceedings at the High Court of Justice at Dublin and Cork 1652-1654 [part 1]', Archivium Hibernicum, 66 (2013), pp. 126-32.

40 TCD, MS 838, Examination of Patrick Modder O’Donnelly, 30 Mar. 1653 , fos $42 \mathrm{r}-3 \mathrm{v}$.

41 TCD, MS 839, Information of Captain John Perkins, 8 Mar. 1644, fos 40r-4v.

42 TCD, MS 830, Examination of Patrick Darcy, 20 Dec. 1653, fos 263r-4v.

43 Ibid., Examination of Hygate Lone, 23 Feb. 1653, fos 240r-2r.

44 Ibid., Examination of Jane Sheiley, 25 Jan. 1654, fos 247r-8v and Examination of John Morgan, 13 Jan. 1654, fos 229r-32v.

45 Ibid., Examination of Charles Conway, 22 Mar. 1654, fos 251r-2v. By the time that Conway gave his testimony in 1654, he had relocated from Galway to Cork. A note on his deposition gives his name as 'Charles Conway (alias Konowan)'. The O'Canavans were hereditary physicians to the O'Flahertys in Connemara. He was the only practitioner in the depositions to use the term 'Professor of Physicke'. His precise qualifications are unknown.

46 Ibid., Examination of Mary Bowler, 7 Mar. 1654, fos 244v-6v and Examination of Martin Linch, 24 Jan. 1654, fos 261r-2v. 
47 For a discussion of some of the challenges of studying Early Modern mental illness, see P. Elmer, 'The care and cure of mental illness', in P. Elmer (ed.), The Healing Arts: Disease and Society in Europe: 1500-1800 (Manchester, 2004), pp. 228-30.

48 TCD, MS 818, Deposition of John Sims, 8 Nov. 1642, fos 104r-5v.

49 TCD, MS 830, Deposition of Christopher Cooe, 21 Oct. 1645, fo. 172r-v.

50 TCD, MS 839, Deposition of John Kerdiff, 28 Feb. 1642, fos 12r-16v.

51 For the case of Lord Clanmorris, see TCD, MS 830, Testimony of John Morgan, 18 June 1653, fos 265r-6v. For the case of Colonel Brian McHugh Boy O’Neill, see TCD, MS 836, Information of William Fitzgerrald, 4 June 1642 , fos $82 \mathrm{r}-6 \mathrm{v}$.

52 TCD, MS 831, Deposition of Jane Stewart, 23 Apr. 1644, fos 73r-4v.

53 TCD, MS 837, Deposition of Elizabeth Crooker, 13 Mar. 1643, fos 4r-5v. TCD, MS 839, Deposition of John Kerdiff, 28 Feb. 1642, fos 12r-16v.

54 See, for example, N. McAreavey, 'Re(-)membering women: Protestant women's victim testimonies during the Irish rising of 1641', Journal of the Northern Renaissance, 2 (2010), pp. 1-22. On England in the 1640s, see E. Peters, 'Trauma narratives of the English civil war', Journal for Early Modern Cultural Studies, 16 (2016), pp. 78-94, and M. Stoyle, 'Memories of the maimed: the testimony of Charles I's former soldiers, 1660-1730, History, 88 (2003), pp. 204-26.

55 TCD, MS 817, Deposition of Ruthe Martyne, 16 Mar. 1644, TCD, MS 817 , fos $209 \mathrm{r}-10 \mathrm{v}$.

56 TCD, MS 821, Examination of Ellice Meagher, 23 Aug. 1652, fo. 259r-v.

57 TCD, MS 818, James Franklyn and Abraham Mootham to Captain Smith, 9 Mar. 1645, fo. 155r-v.

58 TCD, MS 815, Deposition of William Nicholls, 16 Jan. 1644, fo. 340r-v. The surgeon involved is not named.

59 TCD, MS 810, Deposition of Samuell Felgate, 8 Jan. 1644, fo. 232 r-v.

60 TCD, MS 838, Examination of Bryan McIlcrany, 5 May 1653, fo. 168r-v.

61 TCD, MS 810, Examination of Allan Cooke, 7 July 1643, fos 283r-4v, Examination of William Hilton, $6 \mathrm{Jul}$ 1643, fos 285r-6v and Examination of Arnold Bote, 6 July 1643, fos $287 \mathrm{r}-8 \mathrm{v}$.

62 On the wider political context, see R. Armstrong, Protestant War: The 'British' of Ireland and the Wars of the Three Kingdoms (Manchester, 2005).

63 For the Confederates, see M. Ó Siochrú, Confederate Ireland, 1642-49: A Political and Constitutional Analyis (Dublin, 1999).

64 TCD, MS 826, Examination of Donnough O’Healy, 16 Sept. 1652, fo. $168 \mathrm{r}-\mathrm{v}$.

65 L. Brockliss, 'Medicine, religion and social mobility in eighteenth- and early nineteenth-century Ireland', in J. Kelly and F. Clark (eds), Ireland and Medicine in the Seventeenth and Eighteenth Centuries (Farnham, 2010), pp. 73-108. For some specific instances of Irish doctors on the continent, see chapter 2 by Hazard and chapter 10 by Caball in this volume. 
66 For a near contemporary mention of the massacre where O'Healy does not feature, see TCD, MS 823, Deposition of Walter Baldwin, 22 Oct. 1642 , fos $165 \mathrm{r}-8 \mathrm{v}$.

67 Wells, 'Proceedings at the high court of justice [part 2]', pp. 215-21.

68 Other medical doctors from Co. Limerick who feature in the depositions are David Gibbon of Kilmallock, in TCD, MS 823, fo. 180r-v; Thomas Arthur of Limerick, in TCD, MS 829, fos 443r-6v; and Francis White of Limerick, fos 385r-6v.

69 Ibid., Deposition of Dermod Grady, 19 Nov. 1642, fos 295r-6v.

70 Ibid., Deposition of Joseph Keanes, 29 Mar. 1643, fos 314r-315v; also ibid., Deposition of John Harte, 1 Sept. 1642, fo. 152r-v.

71 K. Wiggins, Anatomy of a Siege: King John's Castle, Limerick, 1642 (Bray, 2000), pp. 233-4.

72 TCD, MS 829, Deposition of John Comyne, 31 May 1643, fos 101r-2v.

73 TCD, MS 812, Deposition of Joseph Wheeler and others, 5 July 1643, fos 202r-8v.

74 Ibid.; for another mention of Sallenger, robbing Protestants, see ibid., Deposition of John Moore, 22 Feb. 1642, fos 197r-9v.

75 TCD, MS 820, Deposition of Lawrence Hooper, 31 May 1643, fos $312 \mathrm{r}-15 \mathrm{v}$.

76 For example, at Clonmel, Co. Tipperary, in the early 1650s, the Cromwellian army used the services of two Catholic apothecaries, Walter Brenock and James Sall. National Archives of Ireland, MS CO 451, Extracts from accounts for the precinct of Clonmel, 1650s.

77 TCD, MS 838, Examination of Patrick Modder O’Donnelly, 30 Mar. 1653, fos 42r-3v.

78 TCD, MS 836, Information of William Fitzgerrald, 4 June 1642, fos 82r-6v.

79 Ibid.

80 TCD, MS 835, Deposition of George Wirrall, 18 July 1642, fos 231r-2v.

81 TCD, MS 836, Deposition of Anthony Stratford, 9 Mar. 1644, fos $115 \mathrm{r}-16 \mathrm{v}$.

82 TCD, MS 829, Deposition of Thomas Browne, 19 Nov. 1642, fos 150r-1v; TCD, MS 821, Deposition of Thomas Whiteby, 27 Aug. 1642, fo. 84r-v; TCD, MS 828, Deposition of Stephen Love, 3 Feb. 1644, fos 124r-7v.

83 TCD, MS 828, Deposition of Stephen Love, 3 Feb. 1644, fos 124r-7v.

84 TCD, MS 817, Deposition of Elizabeth Stewart, 26 Aug. 1642, fo. 200r-v.

85 See for example, TCD, MS 816, Examination of Rose McAwhy, 28 Jan. 1653 , fos $274 \mathrm{r}-5 \mathrm{v}$.

86 TCD, MS 826, Examination of William Connery, 20 Oct. 1652, TCD, MS 826, fos 59r-60v and Examination of Phillipp Magragh, 20 Oct. 1652, fo. $59 \mathrm{r}$.

87 TCD, MS 809, Examination of Mullmory O’Loney, 5 Nov. 1641, fos $101 \mathrm{r}-2 \mathrm{v}$. 
88 The night before the planned assault, Lord Maguire lodged in the house of Mr Nevell, a barber, on Castle Street; ibid., Examination of Pattricke MaGwyre, 2 Nov. 1641, fos 69r-70v.

89 Ibid., Examination of Mullmory O'Loney, 5 Nov. 1641, fos 101r-2v.

90 TCD, MS 813, Information of Charles Connor, 10 Aug. 1642, fos $39 \mathrm{r}-41 \mathrm{v}$.

91 Connor also accused 'Owgan a Barber' in Dublin of providing supplies to the rebels. This was presumably Edward Wogan, a barber-surgeon who became a freeman in Dublin in 1632. John Gilbert (ed.), Calendar of Ancient Records of Dublin (19 vols, Dublin, 1889-1944), iii, p. 259.

92 TCD, MS 813, Information of Thomas Fitzgerald, 5 July 1642, fos 71r-2v.

93 Ibid., Information of Dauid Eustace, 5 July 1642, fo. 75 r.

94 TCD, MS 1447, Records of the Dublin Guild of Barber-Surgeons. Unfortunately the guild records for the period 1588 to 1688 have not survived.

95 TCD, MS 822, Deposition of Ann Sellers, 4 Oct. 1642, fo. 177r-v; TCD, MS 828, Deposition of Edward Vauclier, 21 Apr. 1643, fos 284r-5v; TCD, MS 836, Deposition of Edward Saltenstall and George Littlefeild, 1 June 1642 , fos $69 \mathrm{r}-79 \mathrm{v}$.

96 Ibid.

97 TCD, MS 821, Deposition of Richard Sheapherd, 7 June 1642, fo. 122r-v.

98 TCD, MS 830, Examination of Robert Rawlins, 5 Feb. 1654, fos 197r-8v.

99 TCD, MS 809, Deposition of John Mandefeild, 3 Feb. 1642, fo. 293r-v.

100 TCD, MS 838, Examination of William Sterlin, 2 Mar. 1653, fos 60v-1r.

101 Ibid., Examination of Robert ffuthy, 2 Mar. 1653, fos 59r-60r.

102 TD, MS 835, Deposition of Elizabeth Adwick, 4 Jan. 1642, fo. 71r-v. The word 'clothinge' here is a speculative reading of the manuscript.

103 A related problem is posed by the widespread use in Early Modern sources of the occupational label 'merchant'. In the Irish context, this complicates efforts to identify apothecaries in particular.

104 TCD, MS 829, Deposition of Thomas Browne, 19 Nov. 1642, fos 150r-1v.

105 TCD, MS 836, Deposition of John and Isabell Gowrly, 8 Nov. 1642, fo. 57r-v; TCD, MS 830, Deposition of Mary Hamond, 16 Aug. 1643, fos $136 \mathrm{r}-7 \mathrm{v}$.

106 TCD, MS 823, Deposition of Therlagh Kelly, 11 Jan. 1643, fos 173r-5v.

107 TCD, MS 836, Examination of Thomas Dixon, 15 Mar. 1653, fo. 120r-v.

108 TCD, MS 814, Deposition of Henrie Aylyffe, 27 June 1642, fos 176r-9v.

109 TCD, MS 829, Deposition of Thomas Andrew, 10 Sept. 1642, fo. 008r-v

110 Ibid.

111 TCD, MS 821, Deposition of Richard Sheapherd, 7 June 1642, fo. 122r-v.

112 J. Kelly, 'Domestic medication and medical care in late early modern Ireland', in Kelly and Clark (eds), Ireland and Medicine, pp. 109-35.

113 TCD, MS 813, fo. 342r, contains a list of four medical book titles with what appear to be sale prices. This sheet is bound between two others 
that make up deposition of Margaret Browne and Edward Browne, vicar of Timahoe in Co. Kildare. There does not appear, however, to be any direct connection between the list of books and Browne's deposition. The books referred to appear to be sixteenth-century publications of works by Santes Andoynus, Andreas Baccius and Ulrich Hutten, and a collection of medical texts edited by Henricus Stephanus. The Brownes' deposition is at TCD, MS 813, fos 341r-3v.

114 TCD, MS 833, Deposition of George Creighton, 15 Apr. 1643, fos 227r-42v.

115 This was presumably Barnaby Googe's translation of Foure Books of Husbandres, Collected by M. Conradus Heresbachius, of which numerous editions were published in London between 1577 and 1631. The nobleman referred to was Christopher Plunket, second earl of Fingall, whose seat was at Killeen Castle in Co. Meath. He joined the rebellion and died in prison in Dublin in 1649 following his capture at the battle of Rathmines.

116 TCD, MS 833, Deposition of George Creighton, 15 Apr. 1643, fos 227r-42v.

117 TCD, MS 813, Deposition of Edward Williamsonn, 8 Jan. 1644, fo. 312r-v.

118 TCD, MS 830, Deposition of Ann Frere, 8 Jan. 1644, fos 32r-3v. The deposition does not explicitly refer to Frere as a clergyman, but there were several churchmen of that name in the period.

119 Ibid.

120 For a recent publication showing some of the research possibilities, see F. Dillane, N. McAreavey and E. Pine (eds), The Body in Pain in Irish Literature and Culture (Basingstoke, 2016). 